Canadian Art Review

\title{
Exposed Wounds: The Photographic Autopathographies of Hannah Wilke and Jo Spence
}

\section{Tamar Tembeck}

Volume 33, numéro 1-2, 2008

Medical Tabulae: Visual Arts and Medical Representation Tabulae médicale : arts visuels et représentation médicale

URI : https://id.erudit.org/iderudit/1069550ar

DOI : https://doi.org/10.7202/1069550ar

Aller au sommaire du numéro

\section{Éditeur(s)}

UAAC-AAUC (University Art Association of Canada | Association d'art des universités du Canada)

\section{ISSN}

0315-9906 (imprimé)

1918-4778 (numérique)

\section{Découvrir la revue}

Citer cet article

Tembeck, T. (2008). Exposed Wounds: The Photographic Autopathographies of Hannah Wilke and Jo Spence. RACAR : Revue d'art canadienne / Canadian Art Review, 33(1-2), 87-101. https://doi.org/10.7202/1069550ar

\section{Résumé de l'article}

L'article s'intéresse aux autopathographies produites par Hannah Wilke et par Jo Spence inspirées par la lutte qu'elles ont toutes deux menée contre le cancer dans les années 80 et au début des années 90 . Les deux artistes se sont tournées vers l'autopathographie pour réinventer leurs propres images corporelles, ainsi que l'image sociale de leur maladie. En examinant de près leurs productions, l'article décrit les stratégies esthétiques et politiques qu'elles emploient pour transmettre leur expérience. Wilke transforme activement son vécu souffrant en l'image d'un exosquelette blessé, où des marques réelles, ainsi que des signes construits autour de sa douleur sont exhibés sur son corps et par lui. Par cette transformation, l'artiste parvient à exprimer une position critique face aux préjugés culturels qui sont rattachés à (l'image de) sa maladie. Spence, pour sa part, crée une dialectique visuelle du sujet malade, où son image ne peut facilement être réduite aux statuts extrêmes de " victime » ou d'« héroïne ». L'image du sujet qui en émerge demeure dynamique et complexe, et échappe aux stéréotypes préjudiciaux. L’article se penche également sur la dimension performative impliquée dans toute autoreprésentation, et, plus précisément, dans les objets culturels liés à la maladie tels que les talismans et les ex-voto, qui sont décrits par Thierry Davila comme étant des «formes agissantes ». Les oeuvres de Wilke et Spence nous portent à réfléchir sur la lourde responsabilité qu'il nous faut assumer face aux oeuvres pathographiques et aux images de la souffrance.
Tous droits réservés (C) UAAC-AAUC (University Art Association of Canada | Association d'art des universités du Canada), 2008
Ce document est protégé par la loi sur le droit d'auteur. L'utilisation des services d'Érudit (y compris la reproduction) est assujettie à sa politique d'utilisation que vous pouvez consulter en ligne.

https://apropos.erudit.org/fr/usagers/politique-dutilisation/ 


\title{
Exposed Wounds: The Photographic Autopathographies of Hannah Wilke and Jo Spence
}

\author{
Tamar Tembeck, PiiD candidate (ABD), Dfpt. of Art History and Communication Studies, McGill University
}

\begin{abstract}
Résumé
L'article s'intéresse aux autopathographies produites par Hannah Wilke et par Jo Spence inspirées par la lutte qu elles ont toutes deux menée contre le cancer dans les années 80 et au début des années 90. Les deux artistes se sont tournées vers l'autopathographie pour réinventer leurs propres images corporelles, ainsi que l'image sociale de leur maladie. En examinant de près leurs productıons, l'article décrit les stratégies esthétiques et politiques qu'elles emploient pour transmettre leur expérience. Wilke transforme activement son vécu souffrant en l'image d'un exosquelette blessé, où des marques réelles, aınsi que des signes construits autour de sa douleur, sont exhibés sur son corps et par lui. Par cette transformation, l'artıste parvient à exprimer une position critique face aux préjugés culturels qui sont rattachés à (limage de) sa maladie. Spence. pour sa part, crée une dialectique visuelle du sujet malade, où son image ne peut facilement être réduite aux statuts extrêmes de « victıme » ou d'« héroïne ». L'image du sujet qui en émerge demeure dynamique et complexe, et écnappe aux stéréotypes préjudiciaux. L'article se penche également sur la dimension performatıve impliquée dans toute autoreprésentation, et, plus précisément, dans les objets culturels liés à la maladie tels que les talismans et les ex-voto, qui sont décrits par Thierry Davila comme étant des «formes agissantes 》. Les œuvres de Wilke et Spence nous portent à réfléchir sur la lourde responsabilité quill nous faut assumer face aux œuvres pathographıques et aux images de la souffrance.
\end{abstract}

$T_{1}$ he contemporary movement towards autopathographic production can undoubtedly be attributed to the growing visibility of cancer and AIISS in the last quarter of a century. Yet the potent ties between illness and artistic representation reach back at least as far as Antiquity, notably in the guise of objects invested with restorative powers, such as amulcts and talismans. The power attributed to representations tied with illness has not been restricted to their curative potential, however. In the history of art, the exposure of diseased bodics has consistently borne the mark of the abject, and the majority of illness representations in the West have moreover risked colluding in the circulation of stigma. Representations of illness thus also possess a potentially dangerous might, and as such, are often met with a compclling mixture of fear and fascination.

As both Sander Gilman and Susan Sontag have suggested in their cultural analyscs of illness, contemporary representations of disease continue to carry the burden of stigma once attributed, for instance, to nineteenth-century representations of the syphilitic or mentally ill.1 Given the weight of such cultural inheritance, in order to depict ill subjects as well as the subject of illness with full dignity today, artists have sought to avoid proliferating stigmatic attributions to the ill body in spite of the dissemination of its image. Hannah Wilke, a multidisciplinary artist, and Jo Spence, a photographer, each turned their establishcd practices towards autopathography after developing cancer. As Wilke's Intra-Venus series and Spcnce's The Picture of Health? and The Final Project attest, both artists developed aesthetic strategies that complexify the representations of their diseased bodies. Each invests her self-portraits with a presence that confronts stereotypical denigrations of sick subjects.

While the term autopathography is most often employed with reference to autobiographical accounts of illness or suffering that take a narrative form, its definition is broadened here in order to include visual media, such as Wilke's and Spence's photographic self-portraits, which rclate experiences of physical illness first-hand. As public exposures of intimate suffering, autopathographies often employ tactical rhetorical devices that help to shape their affective reception. Viewers are typically torn betwcen embracing or refusing empathy towards the image and towards the subject depicted. In this way, autopathographic works raise significant ethical questions that pcrtain to viewers' responses and responsibilities in the face of images of suffering. Following the examination of selectcd autopathographic works by Wilke and Spence, the problems raised in responding to such images will be explored in greater detail in this essay's final section.

Critical receptions of pathographic works rypically fall along interpretive lines. From the angle of the image's production, (auto)pathography is perccived as a militant act of situated visibility, as a vehicle for catharsis and recovery from suffering, as a performance of identity, and as a relational outreach towards othcrs. These interpretive perspectives come together in the bclief that the practice of (auto)pathography is intrinsically restorative, if not therapeutic. From the angle of the image's reception, autopathography is decmed to convey firsthand documentary "rruth" of an experience of illness. It is also surmised that the rcception of autopathographic reprcsentations can provoke vicarious catharsis in their viewers. While this suggests that autopathographic works potentially build bridges between their producers and receivers, such images also effect a relational memento mori, and as such may instead widen the affectivc and communicative gap.

\section{Autopathographic Performativity}

The above interpretations all credit pathographic representations with a certain power to act. The performative dimension of the pathographic image is tied to its function as a pharmakon: 
art can enable finding a cure within a poison, which here takes the form of creativity within disease. ${ }^{2}$ For Arthur W. Frank, this is the "dangerous opportunity" afforded by illncss, and the very reason for which autopathography can be morally restorative. ${ }^{3}$ The remedial function of art harkens back to the birth of aesthetics, with Aristotle's Poetics. Aside from Aristotle's (and in the twentieth century, Bertolt Brecht's) privileging of the dramatic form as containing a morally curative potential, there exist a number of pagan and religious objects that embody a similar potential for positive transformation in both their producers and receivers.

In his description of the ancient potency of icons, Thierry Davila introduces the notion of an "acting form" ("forme agissante") to explain their performative quality: "The image must go beyond the exclusive scope of pure contemplation or distanced veneration in order to reach a realm in which direct action onto bodies and events constitutes its veritable raison d'etre." 4 The figure of the ex-voto can similarly be regarded as a type of acting form. An ex-voto functions as the incarnation of a prayer or wish, and tangibly commemorates ensuing health improvements. As a fabricated object, its role is to intercede between the person making demands and a divinity. In effect, the ex-voto actually performs what is being prayed for: it acts both as the sign of a praycr and of its accomplished result, but also as a depository for faith and psychic investment that is dedicated towards healing. As we will see, the autopathographic photographs of Wilke and Spence are likewise invested with such complex acting potential. On the one hand, the creative process of self-representation offers the artists a means by which to transform their subjective experiences of illness. On the other, the acting power of their pathographic images also potentially spills forth, in order to alter viewers' typically stigmatizing perceptions of disease.

The performative dimension of the autopathographic image is exacerbated by its ties to autobiography and to self-portraiture. According to Judith Butler, the fiction of the subject "I" is instantiated through accounts of the self, in addition to its everyday performanccs. ${ }^{5}$ Such accounts can take the shape of testimony or autobiography, both of which are closcly linked to the functions of autopathography. In any account of the self, the construction of a symbolic "I" depends upon the concomitant projection of a linguistic and conceptual "you." As Butler explains, accounts of the self are inevitably structurcd in the form of an address to another. ${ }^{6}$ Outside of this structure of address, the "I" and its referent simply do not exist. It is through an interlocutory address that the account of the self cnables and even instantiates the cxistence of the "I" and its referent. In this sense, any autobiographical account that is directed towards a receiver, such as a public autopathography, effectively and performatively constructs the "I" to which it refers.
As in any autobiography, then, the account of the self always remains at lcast a partial fiction. ${ }^{7}$ Amelia Jones examines the theatrical exaggeration conveyed in photographic self-portraits by Claude Cahun, Cindy Sherman, Hannah Wilke, and others. For Jones, their self-portraits are all characterized by noticeable artifice. 'The exaggerated performativity in each artist's self-display appears to "foreground the "I' as other to itself." ${ }^{8}$ In their works, the supposedly represented "I" remains forever ungraspable and irreducible either to the image, or to its referent (which here consists in the artist as both the author and subject of her work). Thus, in light of Butler's and Jones's insights, at least two levels of performativity can be found in feminist autopathographic images: on the one hand, the constitution of the subject "I" through autobiographical self-representation, and on the other, the uprooting of said subject through the highlighting of all (gendered) representations as constructed fictions.?

Wilke and Spence have each exploited the performative contradictions implicit to their self-representations. Not only do they disarm conventional expectations pertaining to the depiction of female bodies, but they also counter the continucd marginalization of diseased subjects in representation. Both artists' creative parhs were significantly informed by fominist politics, as well as by their own autobiographies. In each case, their ultimate reflections on illness and dying were preceded by earlier treatments of the same subjects. Before her cancer diagnosis, Wilke extensively documented her mother's experience of breast cancer, surgery, and hospitalization in the exhibitions So Help Me Hannah (1978, I.S.I, New York City) and Support Foundation Comfort (1984, Ronald Feldman Fine Arts Gallery, New York City). Similarly, before developing terminal leukemia, Spence constructed a didactically oriented photographic analysis of her experience with breast cancer for The Picture of Health? (198286), a touring exhibition, first shown in 1983 at Camcrawork in London. In their distinct ways, Wilke's and Spence's autopathographic productions are integral to the artists' lifclong creative practices, which have consistently engaged aesthetic, political, and even metaphysical concerns through the (sclf-)representation of female bodies in particular, and critical perspectives on women's social rolcs in general. What follows is a brief glimpse into the artists' manipulations of the autobiographical mode in order to convey their experiences of illness. Both artists inject their representations with an authorial presence that is at once playful, troubling, and powerfully affirmative.

\section{Hannah Wilke: Autopathography as the Construction of a Wounded Exoskeleton}

A New York-based visual and performance artist, Hannah Wilke became notorious for her body-centred work from the mid-1960s onwards. Well before Judy Chicago popularized her 

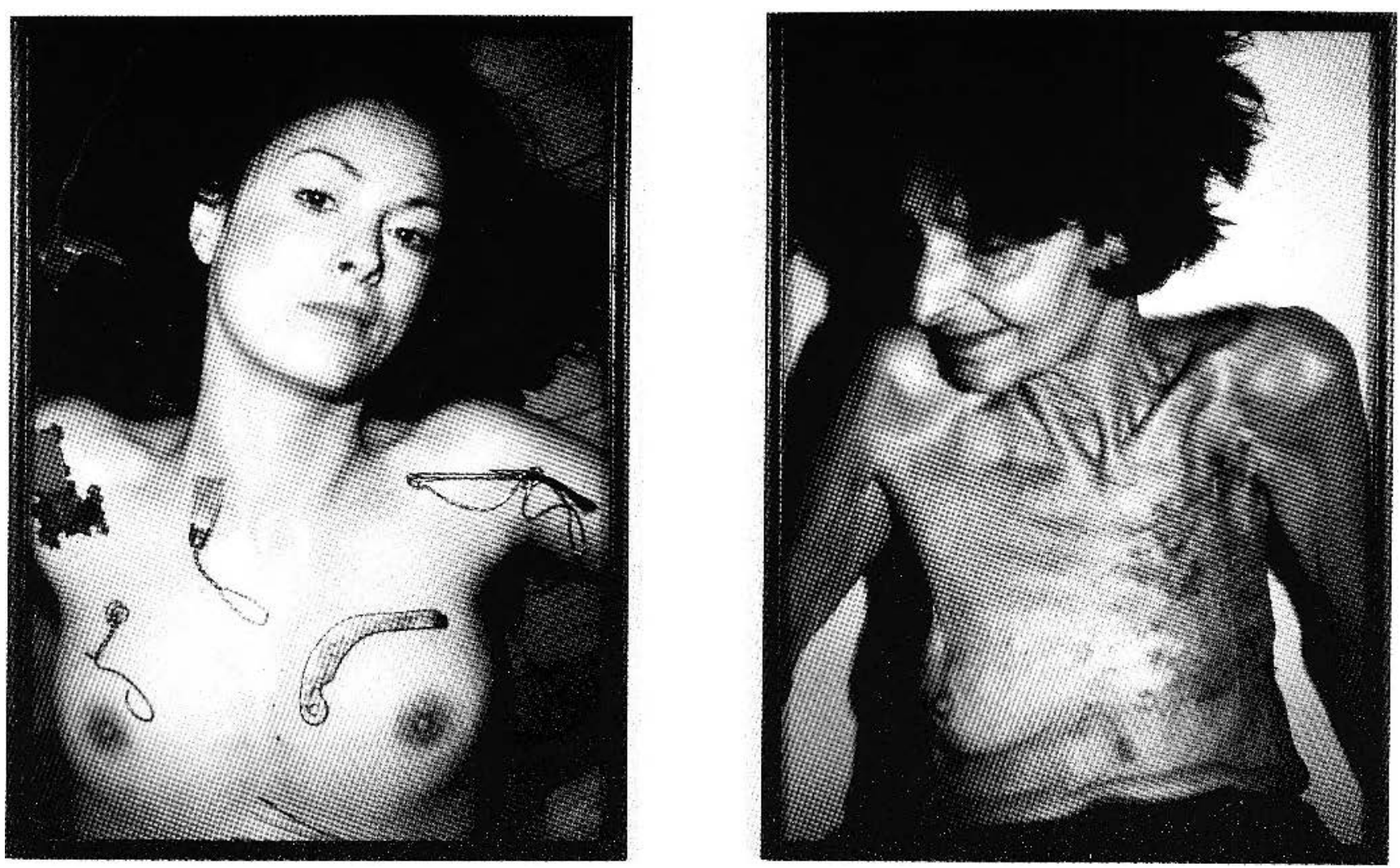

Figure 1. Hannah Wilke. So Help Me Honnah Series: Portrait of the Artist with Her Mother, Selma Butter, 1978-81. Cibachrome photograph diptych, each panel $101.6 \times 76.2 \mathrm{~cm}$ (Courtesy of Ronald Feldman Fine Arts, New York; photo: Dennis Cowley / (C Marsie, Emanuelle, Damon and Andrew Scharlatt/Licensed by VAGA. New York. NY)

central core imagery, ${ }^{10}$ Wilke was interested in reclaiming the physicality of womanhood as a source of celebratory pride. Her early latex and clay sculptural works, multiplied scrially and in various colours, resembled a blossoming of labial and vaginal forms. It was not long before Wilke's signature figuring of the womb was transposed into that of the wound: through the motif of the scar, W'ilke showed that the generative potential of womanhood and beauty could also become painful, victimizing, and destructivc. In particular, her wearable gum sculptures in S.O.S. Starification Object Series (1974-82) played on the tension between "starification"-commodity culture's glorification of popular media heroines-and "scarification"- the invisible wounds that invariably emerge from belonging to a rigidly defined social group, as well as the physical markers that situate individuals politically within society. Wilke's placement of gum scars onto her body recalled the beautifying process of scarification in certain African and Polynesian cultures, a ritual whose purpose also serves to re-inscribe visible differences between the sexes. When reading the gum ornaments in tandem with
Wilke's seemingly playful posturing for the camera in a 1970 s North American context, the gum wounds can readily be taken as the stigmata of women as "others" in a patriarchal sociery. 11

The motif of symbolic woundedness, as tied to the social experience of femininity, prefigured Wilke's development of physical illness, a lymphoma diagnosed in 1987 and around which the Intra-Venus series was articulated. Whilc Wilke's work from the 1970s suggests that the "wounds" of femininity, as experienced in patriarchal culture, might one day be removed or transformed, the same could unfortunately not be said of her disease, which proved fatal in 1993. Besides the psychoanalytic connection between the sight of the female body and (the threat of) castration, it is possible that Wilke's visual association of womanhood with woundedness might have stemmed from witnessing her mother's breast cancer. In effect, Wilke began to perform nude in 1970, after her mother's mastectomy. ${ }^{12}$ Wilke's exposure to her mother's "real wound" may thus have inspired the analogy she drew in turning the hidden, psychic wounds of femininity into meaningful physical marks. That wounded- 
ness should appear as a motif to figure both visiblc and invisible pain is not surprising, considering the incommunicable nature of suffering. If pain, both moral and physical, is pre-symbolic, ${ }^{13}$ changing, and ungraspable in nature, then the transmission of such experience needs to be translated into a clcarly identifable form. From this perspective, the motif of the wound not only emerged in Wilke's practice as the physical consequence of illness, but also was employed as an active, signifying mark, which visibly indicated the non-figurable pain that brought it into being.

Portrait of the Artist with Her Mother Selma Butter (fig. 1) from the So Help Me Hannah Series (1978-81) effects a complex symbolic bridge between the suffering experiences of morher and daughter through the representation of real and symbolic wounds. The diptych portrays the naked upper bodies of Wilke on the left and her mother on the right. Signs of disease are clearly visible on Selma Butter's chest, ravaged by a mastcctomy scar, upon which small red tumours are surfacing anew. Wilke emulates the marks on her mother's body by placing found objects onto her own healthy torso. These objects recall items that Wilke had collected for her ex-lover, Claes Oldenburg.

Through the diptych format, Wilke both contrasts and draws an analogy berween her mother's body and her own. In juxtaposing the two figures, and including a title that clearly identifies the sitters as mother and daughter, Wilke ensures that the figures are read as mutual alter egos. Wilke's duplication of her mother's wounds on her own body is displayed against the "real thing," thereby highlighting her gesture of posing and quotation, but also emphasizing the correspondence between the two bodies. Through the side-by-side placement of mother and daughter as partial (genetic) equivalents, Wilke also juxtaposcs the mutually exclusive timescapes of youth and age, living and dying, and existence before and after illncss. Such a temporal conjunction is reminiscent of traditional vanitas portraits, where young women in attitudes of self-admiration arc depicted next to skulls or hourglasses that allude to their inescapable deaths.

By her own account, Wilke took thousands of photographs of her ailing mother in the hope of (emotionally) curing both mother and daughter. ${ }^{14}$ In this light, Wilke to a certain extent updated the practice of the painted ex-voto with her camera, both performing an action dedicated towards a curc, while at the same time commemorating that gesture with the resulting photograph. The act of taking pictures offered Wilkc an opportunity to be intimate with her mother and to collaborate with her in a life-affirming, creative endeavour; yet it also scrved a somewhat morose, apotropaic purpose, in anticipation of what was to come. As Joanna Frueh writes, "Wilke counters loss by presenting loss, the departure of her mother." 15 Representing her mother's physical wounds before she died might have helped Wilke to resolve anticipared mourning. The wounds became acting forms in representation, reclaimed by Wilke in order to assert herself and her mother against the desolation caused by illness and approaching mortality. But in taking photographs for the purpose of curing her mother, there is also some suggestion that Wilke wished her symbolic wounds might effectively replace the real ones. Wilke longed to take on her mother's pain, and to endure her suffering in her place. For Wilkc, undoubtedly feeling disempowered in front of her mother's illness, this diptych became an explicit and efficient means for her to share her mother's burden.

The fact that Wilke's symbolic wounds here are made up of objects resembling those destined for her cx-lover suggests that she did not altogether forget the militant discourse that animated her S.O.S. works. Wilke, in fact, sucd Oldenberg for alimony following their separation, and was evidently upset about the outcome of their relationship, both emotionally and materially. The motif of the wound, then, in this diptych, is a combined figuring of at least four types of pathographic stigmata: the physical scar that resulted from her mother's surgery, with its inverse figuration of an "absent" breast; the emergent tumours that are in its place, and their indications of a malignant cancer in lieu of life-giving, maternal nourishment; the symbolic wounds devised by Wilke in order to depict, transmit, and even take on the suffering of her mother's illness; and the combined references of those wounds to two painful losses for Wilke, her separation from Oldenberg and the probable departure of her mother.

The transformation of suffering into communicative signs such as Wilke's symbolic wounds allows for the translation of pain, whether emotional or physical, into a metaphorical exoskeleton: a mark of intimate somatic and psychic experience that is made public and rendered visible on the body. Although this exoskeleton remains attached to the body, its symbolic referents are not restricted to physiological experiences. Arthur Kleinman uses the term to define the invisible social stigma of disease, which he describes as "that exoskeleton": "the carapace of a culturally marked illness." 16 But unlike the moral stigma that is attributed to sick bodies, the metaphoric exoskeleton devised by the autopathographic artist does not necessarily spoil the artist's identity. 17 Instead, the production of visible, symbolic wounds is precisely what enables her expression of pain, and her conscientious manipulation of the standard cultural mcanings of disease. In other words, while the artist is both socially and physically marked by illness, she reworks this inscription for herself through autopathography. In so doing, she provides a vehicle through which others can in turn reconsider their understandings of sickness and its impacts on identity. The symbolic function of the exoskeleton therefore involves the transfiguration of a social reading of the body into an affirmative writing onto the body. It consists of a purposeful auto-scarification, which also 

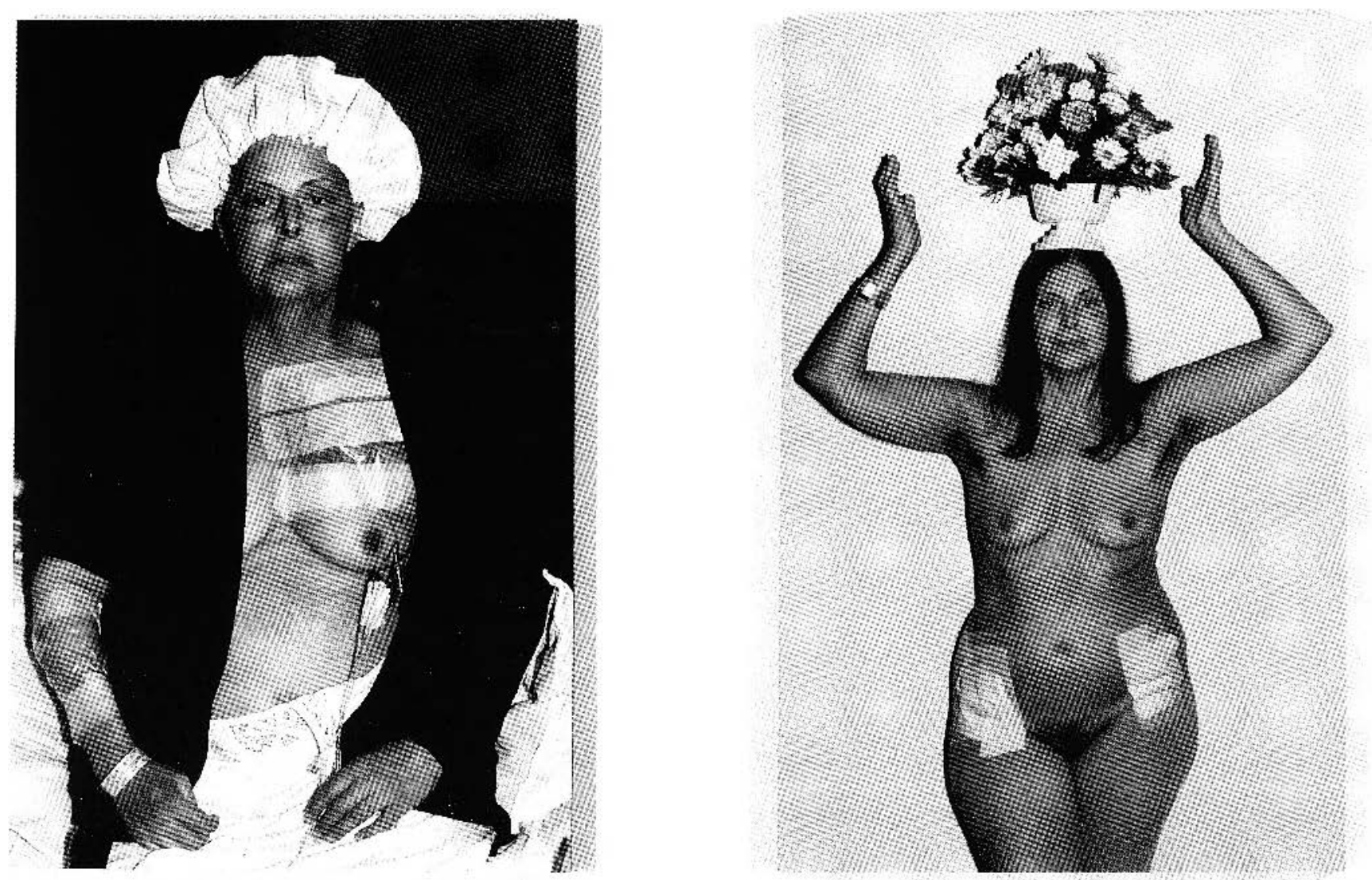

Figure 2. Hannah Wilke. June 15, 1992 / Jonuory 30, 1992: No. I from Intra-Venus, 1992 93. Performalist Self-Portrait with Donald Goddard. Chromagenic supergloss prints, two panels, each $181.6 \times 120.7 \mathrm{~cm}$ (Courtesy of Ronald Feldman Fine Arts, New York; photo: Dennis Cowley / (C) 2006 Donald Goddard).

reflexively indicates how the body is culturally marked, be it by gender, ability, or race. ${ }^{18}$

While Wilke's early figuration of a wounded exoskeleton sought to expose ideological conditionings of women's representations, in her later works symbolic wounds coincided with physiological ones. Wilke's autopathographic production was originally destined for an exhibition to be entitled Cure, but her Intra-Venus series was only posthumously displayed at the Ronald Feldman Fine Arts Gallery in 1994. In addition to "performalist" 19 photographs constructed with her partner, Donald Goddard, the works shown in Intra-Venus included watercolour self-portraits, sculptural arrangements made out of medical paraphernalia, and drawings rendered with the hair that Wilke lost as a result of her chemotherapy treatments, effectively making up a public reliquary of her person.

The revised title for the exhibition, Intra-Venus, drawn from Wilke's original naming of her photographic series, refers to what lies beneath cult representations of feminine beauty catering to a scopophilic gaze. From a psychoanalytic perspectivc, it invokes going inside this icon of femininity, penetrating Venus in order to see what she hides: not just the infamous "horror of nothing to see," 20 but the horror to which this void ultimately refers, the inverse of the womb-the tomb, or death. At the same time, the title also evokes the intravenous trespassing of the medical gaze beneath the skin-ego, 21 and its subsequent transformation of a patient's moral and physiological lifeblood.

Wilke's photographic self-portraits from the Intra-Venus series put forward a collection of familiar iconic references, making it clear that she was intentionally commenting on representational conventions in popular media and art history. In one diptych (fig. 2), a pot of flowers crowns Wilke as a bandaged Venus, while a shower cap recalls "the headpiece in a Dutch portrait."22 Elsewhere, she wears a blue hospital bedsheet over her head in imitation of the Virgin Mary, and in a close-up shot rests her hands on her cheeks in the pose of a fashion model 

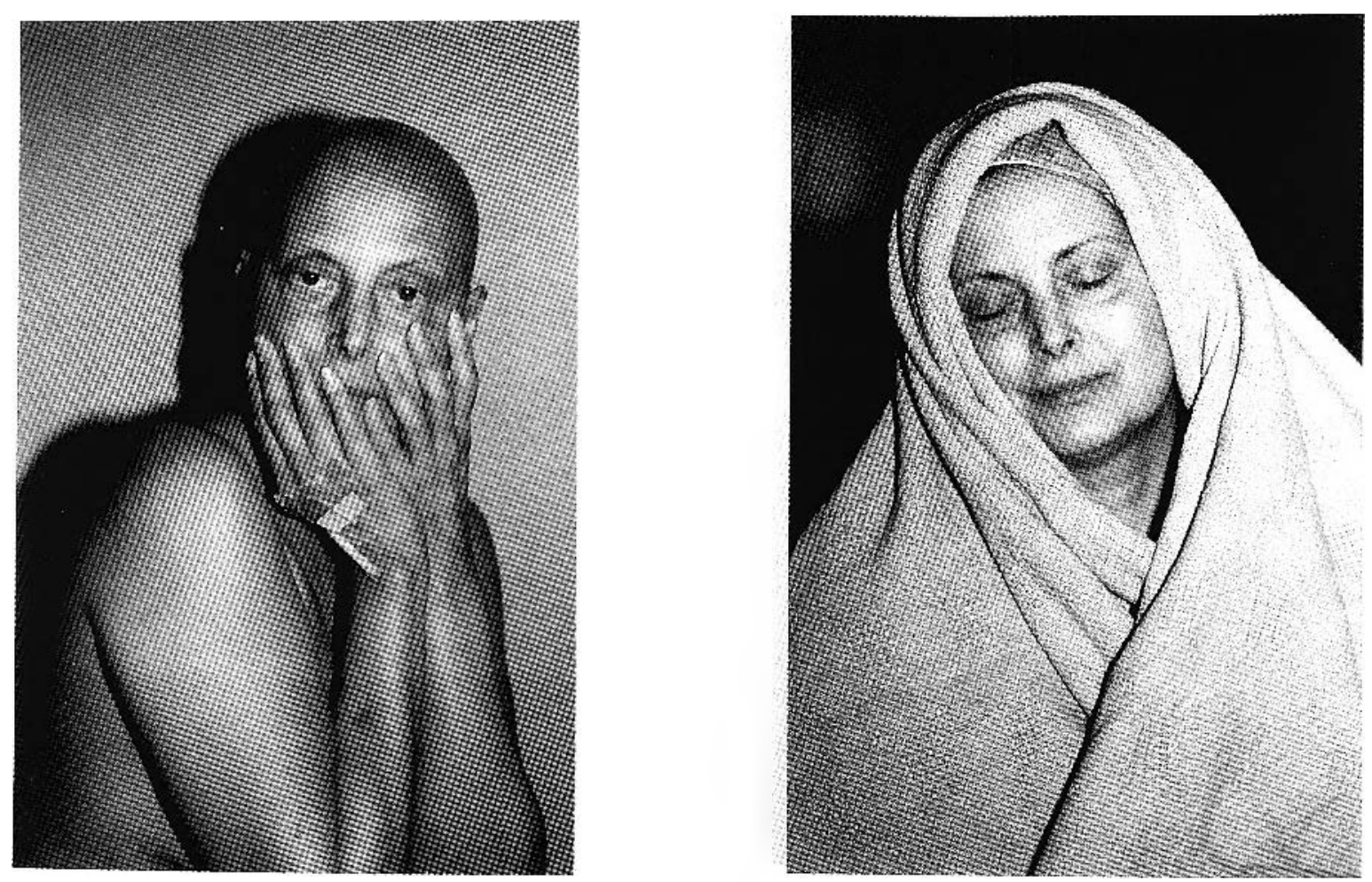

Figure 3: Hannah Wilke. July 26, 1992 / February 19. 1992: No. 4 from Intra-Venus, 1992-93. Performalist Self-Portrait with Donald Goddard. Chromagenic supergloss prints, two panels, each $181.6 \times 120.7 \mathrm{~cm}$ (Courtesy of Ronald Feldman Fine Arts. New York: photo: Dennis Cowley / (C) 2006 Donald Goddard).

(fig. 3). As a standing nude, she presents herself as a Botticelli Venus who has lost all her flowing hair, and as a cheery cover girl she exposes a large tumour on her neck. Wilke revisited countless representational archetypes of women in these self-portraits, adding various light-heartedly blasphemous alterations to them in order to disturb their reception. By conspicuously including her own commentary in these aesthetic formulas, she reveals them to be prescriptive stereotypes that generally leavc no room for the representation of "deviant" bodies.

The resulting overall effect in Wilke's Intra-Venus photographic self-portraits is one of intentional presentation: a putting forward of herself as a body made for display, acutely aware of the conventions by which it is framed, and expecting to be looked at. But in her knowing deviance from the norms for representing an idealized body, Wilke also lays barc the standard expectations that govern women's representations. Here, instead of interrupting the viewer's visual consumption of her body through the inclusion of incongruous gum scars, it is her "real wounds" - and more importantly, her transformation of those wounds into a symbolic exoskeleton-that do the criti- cal work. Their disturbing function is compounded by Wilke's resolute, authorial gaze.

Elsewhere in the series, however, Wilke's presence is more pointedly confrontational. In one diptych, she appears to emit a silent scream (fig. 4), protesting her pain and urging viewers to pay attention to the image of her suffering. On the second panel, her nose is clogged with cotron and skins sloughs off her tongue. It seems as though she hardly has the energy to keep her mouth open. The conscious criticism that transpires in these images is contrasted by another group in which Wilke discloses her vulnerability. One photograph shows Wilke sleeping in her hospital bed, naked, bandaged, and pierced by a PIC line, her mouth hanging flaccidly open. In another, she sits on a portable toilet, naked again, with a seemingly content expression on her face despite her desolate surroundings.

The cohabitation of such contrasting voices in the selfportraits of Intra-Venus attests to the "biographical disruption" often effected by illness. ${ }^{23}$ Disease is generally thought to interrupt a sufferer's "life plan" 24 and to fragment his or her sense of 

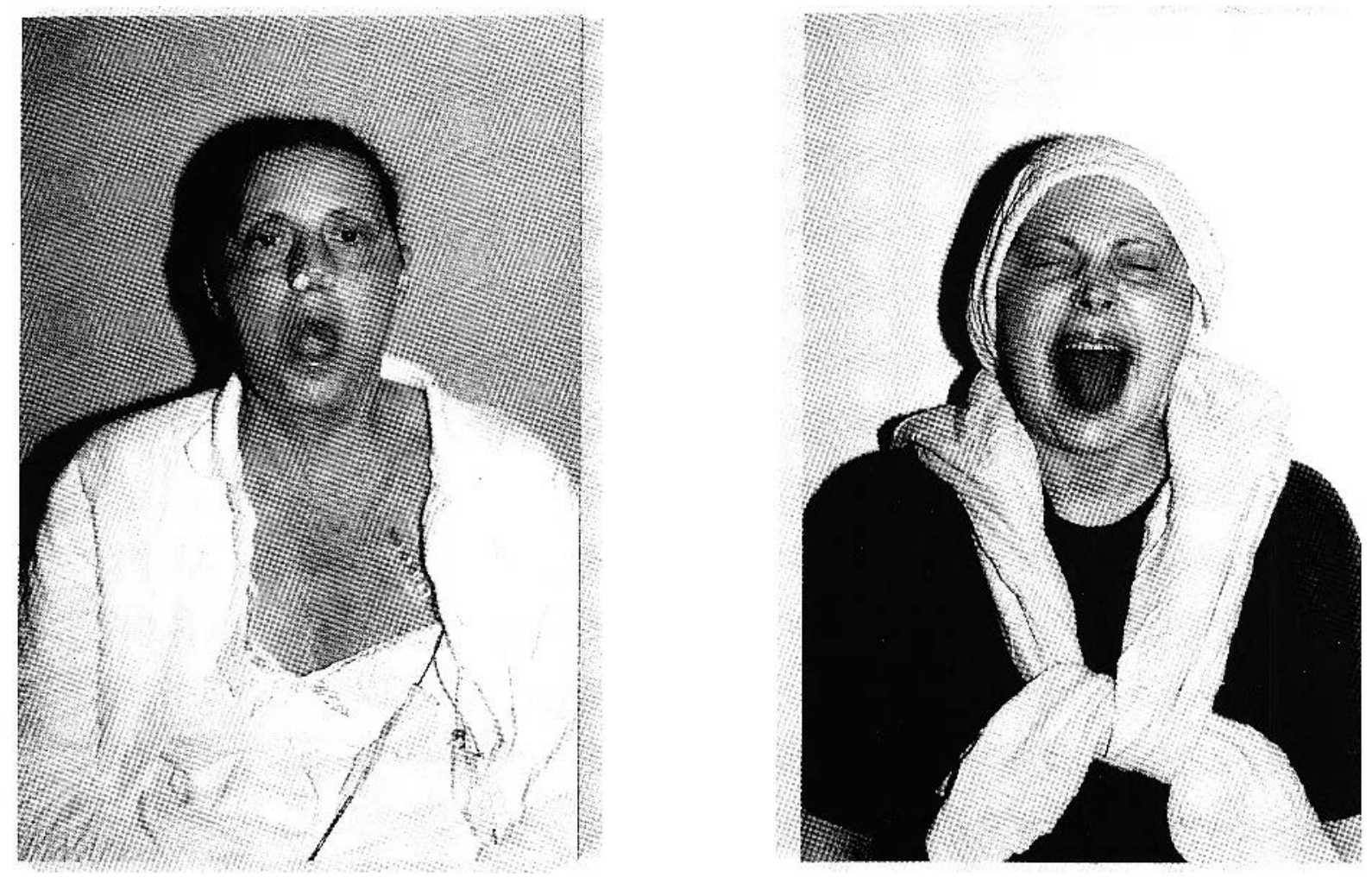

Figure 4. Hannah Wilke. June 10, 1992 I May 5, 1992: No. 5 from Intra-Venus, 1992 93. Performalist Self-Portrait with Donald Goddard. Chromagenic supergloss prints, two panels, each $181.6 \times 120.7 \mathrm{~cm}$ (Courtesy of Ronald Feldman Fine Arts, New York; photo: Dennis Cowley / (c) 2006 Donald Goddard).

self. As Jean-Luc Nancy explains in his literary autopathography, L'Intrus, in the experience of illness the "I" who suffers simply cannot be reconciled with the "I" who is accustomed to not suffering, yet both coexist. 25 The process of autopathography does not necessarily resolve this subjective split, nor does it even presume that the subject needs to be holistically (re)unified. However, in evoking the multiple facets of living with illness, the autopathographic process enables the artist to garner a measure of control over her experience, and to gain some agency in its representation.

Autopathography also holds a compensatory function in terms of the phenomenological experience of illness. The physical pain that accompanies disease entails a sudden focus on corporeality, where the body was once invisible. René Leriche reminds us that "health is the silence of the organs"26; in illness, however, the body suddenly speaks loudly in pain, and is often incomprehensible. The transformation of pain into a symbolic representation allows for its experience to be at least temporarily tamed. Its communication, likewise, helps to lighten the burden. In depicting herself through the image of her diseased body, the artist not only manipulates her experience of illness firsthand and its impacts on her subjective and somatic selves, but also constructively affects the outward perception of herself as a stigmatized, suffering being.

While it is true that Wilke's posing in Intra-Venus might articulate a feminist and even a post-colonial critique of patienthood and the mcdical establishment, those who knew her insist that it was first and foremost a celebration of life, with its many contradictions. ${ }^{27}$ Intra-Venus was about pursuing Wilke's regular daily work, all the while charting the passage of time and the changes in her body. Her familiar creative process was invested with a transformative potential, which, if it did not heal her, could instead contribute to altering social perceptions of illness and to countering the ill patient's premature social death. Wilke's autopathographic work also consisted of a metaphysical investigation within a secular context. As both sitter and photographer in these self-portraits, she held up the vanitas mirror to the fragile state of existence between life and death, turning her experience of the precariousness of human life into a potential point of empathic contact with 
the viewer. By depicting the "kingdom of the sick," 28 that ambiguous territory between the living, the dying, and the dead, illness representations such as Wilke's contain an acting potcntial that might even reach the ethical scnsibilities of their viewers. Before furcher discussing this aspect in the reception of pathographic images, we turn to the work of British artist Jo Spence.

\section{Jo Spence: Empowerment through Autopathography}

In Spence's practice, the performative efficacy of autopathography has primarily to do wich its thcrapcutic power and its ability to facilitate popular education. I.ike Wilke's, Spencc's early work was highly informed by feminism, but hers took on a distinctly Marxist slant. Her acsthetic choices were notably inspired by the tactics of Bertolt Brecht, which aim to promotc critical rcassessments of social behaviours on behalf of the viewer. In this vein, Spence worked on many community-bascd photo cducation projects, and collaborated on a number of group works with the Hackney Flashers Women's Photography Collectivc, including the exhibitions Women, Work and Wages (1973-75) and Who's Still Holding the Baby? (1978). These exhibitions combined traditional documentary photography with tcstimonial accounts, newspaper clippings, cartoons, and educational material, presented to vicwers in such a way as to cntice a Brechtian critical awakcning. In these and most of Spence's subsequent exhibitions, photographs and print documents were laminated in order to facilitatc transportation. 'They werc often prescnted in unorthodox cxhibition spaces, more accessible to an audience that would not be drawn to traditional galleries. Spence's practice in this sensc was always politically engaged: in sccking to disseminate knowledge as a tool for individual empowerment, popular education through photography served as a form of pragmatic activism for Spence.

In 1982 a routinc checkup revealed that Spence had breast cancer. From this point onward, her work moved from a focus on class- and gender-bascd group identities towards questions of individual subjectivity and health, both mental and physical. Rather than agrec to undergo the mastectomy that had been ordered, Spence opted for a lumpectomy and treatments from traditional Chinese medicinc. The following ycar she cnrolled in a co-counselling course, and from then on her photographic work combined the mulciple facets of her acsthetic and political interests. Spence continued to use activism, popular education, and humour in her exhibitions, and her private practice before the camera evolved into a process described as phototherapy, a technique that she developed in collaboration with her cocounsclling partner, Rosy Martin.

Like Spence's earlier projects, the exhibition The Picture of Health? distinctly sought to cducatc its viewers. Having con- ducted extensive research on brcast cancer treatments, Spence found that she had been secretly enlisted as a participant in a clinical trial. This explaincd her original scheduling for a mastectomy, in spite of the fact that survival prognoses after masrectomies were far lower than after lumpectomies. Spence's discovery of altcrnative health treatments also prompted her to makc these less conventional practiccs public, to integrate them into the visual references available to Britons so that they would know of other treatment. She published tcxts and photographs in health magazines and set up her own informal brcast canccr resource centre at homc. The critical faculties Spence once sought to awaken in her viewers in terms of their gender and class positions were being reoricnted towards a form of patient empowerment and cducation.

Spence's sudden confrontation with her own mortality via illness and the ensuing radical change in her everyday life, notably her dict and exercise regimen, were documented in the cxhibition The Picture of Health? What is also clcarly transmitted in this project is a critique of the medical system that takes the form of sousveillance: myriad snapshots taken from the point of view of the bedridden that reverse the clinical gaze and an assemblage of documents that contradicts the health and illness discourscs of dominant media. While Spence was reaching out to others in similar positions of disempowerment, her exhibition was also geared towards cducating health practicioners about patients' cxperiences in the medical field.

In Spcnce's documentary and therapeutic practicc, the cmpowerment of the patient as subject, rather than as object, took place to a large cxtent post facto, through the re-enactment of particularly traumatic moments in the hospital ward. (One of the themes broached through photochcrapy aftcr Spence's surgery was her feeling of infantilization, the utter helplessness and discmpowerment to which a patient is subjected as she waits for her turn under the knife (fig. 5). Another scrics makcs reference to the fighting spirit cancer patients are expected to conjurc up when they are in fact at thcir most vulnerable (fig. 6). Spence acts out before the camera the difficulty of conforming to what medical sociologists call the "good patient," one who adheres to regulated sick-role behaviours, including that of wanting to get better. ${ }^{29}$ She frames these pressures within the dialectic of being cither a heroine or a victim. Through the use of delibcratc editorializing, Spence makes a critical parody of the reductive typecasting of sick subjects in the social imaginary.

Cirash Helmet Portrait (fig. 7) offers a clear example of Spence's use of strategic contradictions. The portrait displays Spence's naked upper-torso, her left arm raised above her hcad to expose hor lumpcctomy scar. She wears a motorcycle helmet, a deliberately intrusive element that appcars to be incongruous with the action of showing her wound and in stark contrast to the vulnerability it signifies. According to her collaborator Terry Den- 


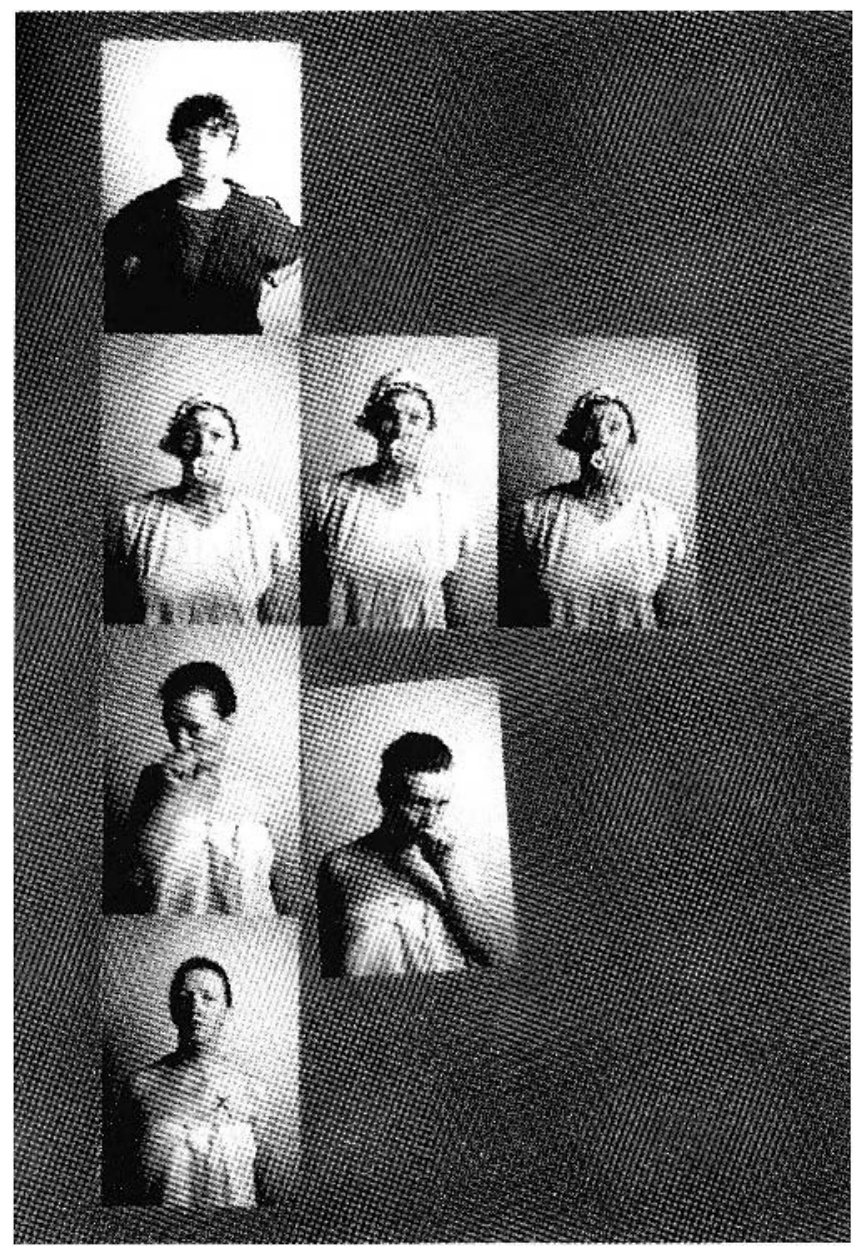

Figure 5. Jo Spence / Rosy Martin. Infontilization, 1984, from The Picture of Health? 1982 86. Photographs laminated on card. $70 \times 50 \mathrm{~cm}$ (@) The Jo Spence Memorial Archive).

nett, who shot the photograph, this strategy was also inspired by the Brechtian invocation to "make strange," to interrupt, to contradict the overall social and visual tableau of the patient as either victim or heroine, winner or loser, morally and physically strong or wcak. 30 "Making strange" is a key performative tactic in Spence's autopathography. The use of built-in contradictions in the image ensures that its subject matter remains unresolved in either direction. In this way, the image also accounts for the irresolvable aspects of experiencing illness more faithfully. When hospitalized, for example, an individual is thrust into a physical state of presence that is torn between serving the surgical needs of the body as machine and the subjective needs of the body as a space of agency. Hardly ever either one or the other, the patient is most often both at once, or caught somewhere in between.

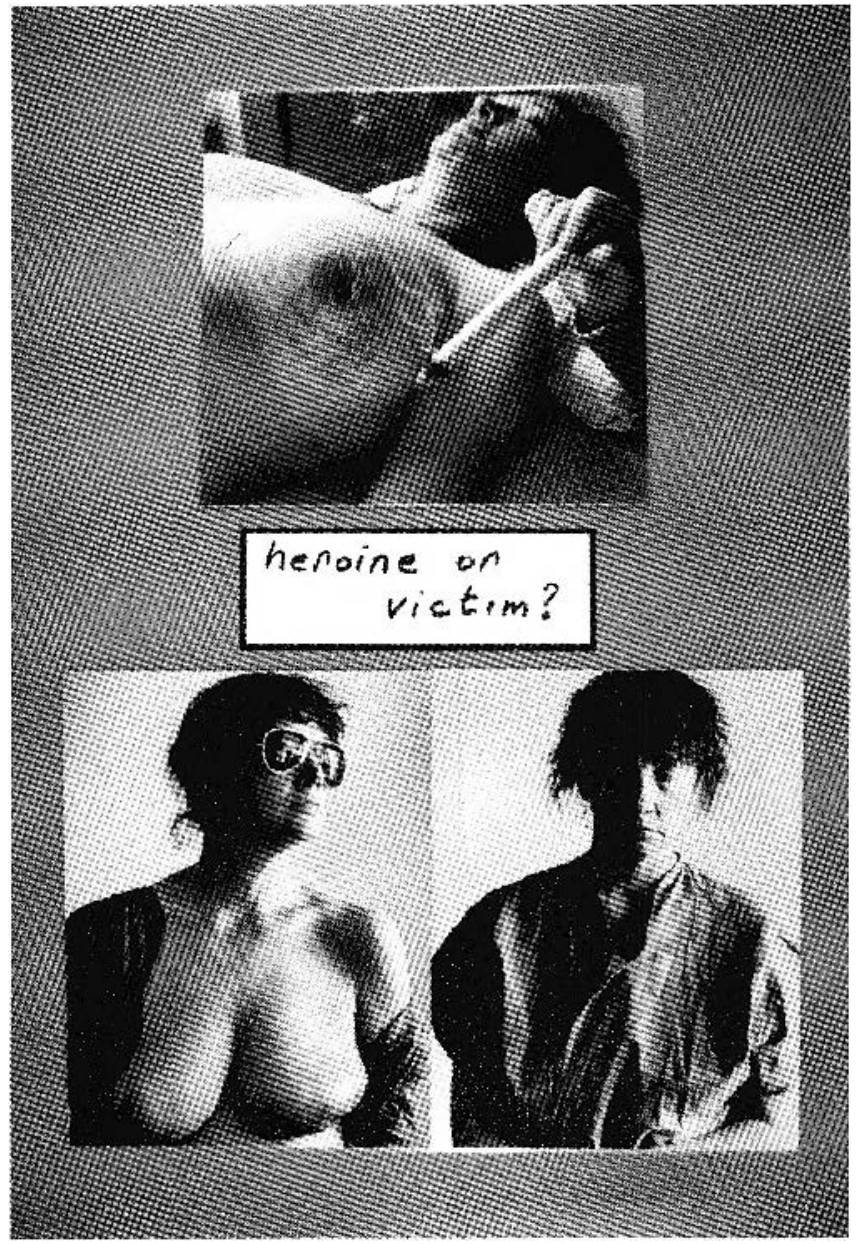

Figure 6. Jo Spence / Terry Dennett. Heroine or Victim? 1984, from The Picture of Heolth? 1982-86. Photograph, $70 \times 50 \mathrm{~cm}$ (C) The Jo Spence Memorial Archive).

Images such as Crash Helmet Portrait allowed Spence to look back at the authoritarian order, incarnated in this context by members of the medical staff, and to counteract the anonymity of her experience as a patient. 'They also enabled her to positively articulate the continued lack of resolution in her experience of illness, and to present this changing state-a productive malaise that she referred to as "dis-ease"-in a generative rather than a derogatory light. Spence looks directly at the camera in these images, secure in her self-representation. But the act of showing her wound here refers to everything that remains unhealed, and that risks being forgotten. As we saw in the previous section, Wilke sought to expose her hidden wounds through the construction of a symbolic exoskeleton. Here, Spence aims to reveal the wounds that the medical gaze is not trained to see. The next example attests to one of its blind spots. 


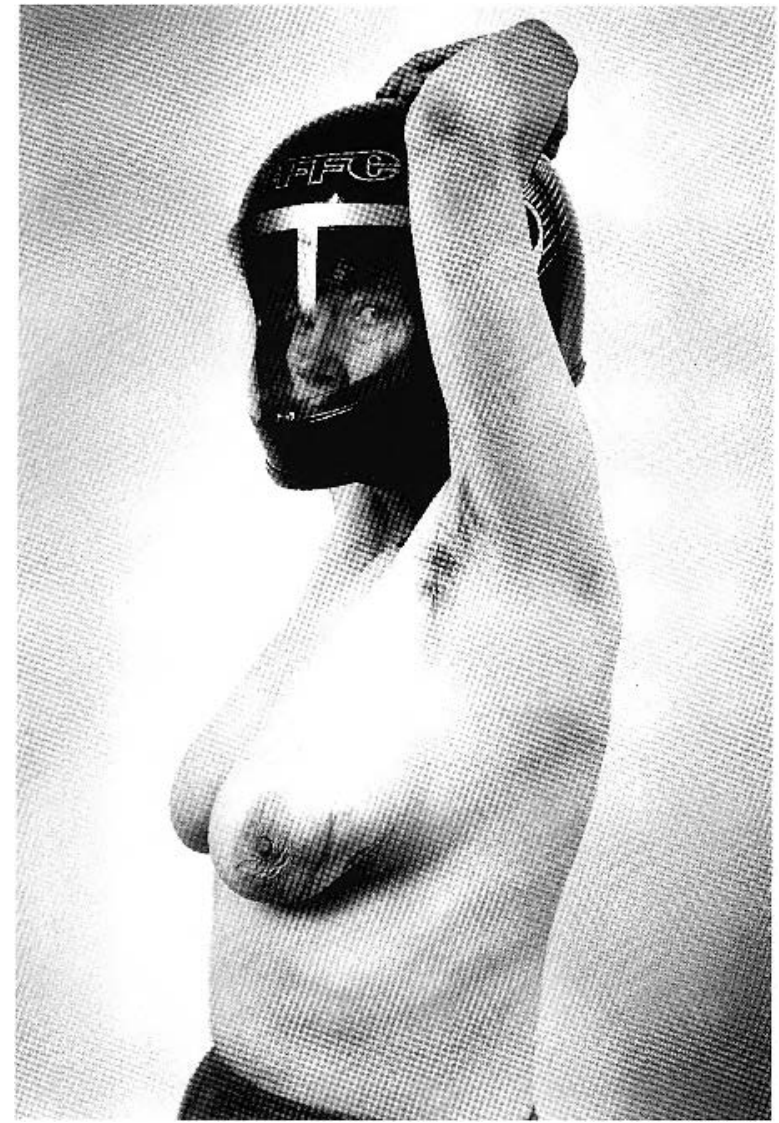

Figure 7. Jo Spence / Terry Dennett, Crash Helmel Portrait, 1983. from The Concer Project. Photograph, $70 \times 50 \mathrm{~cm}$ (C) The Jo Spence Memorial Archive).

On the day when Spence was scheduled for her lumpectomy, the surgeon entered the room, marked an $\mathrm{X}$ above her breast and declared, "This is the one that's coming off." 31 Spence asked Dennett to take a snapshot of her with this $\mathrm{X}$ right after the incident occurred. In a subsequent phototherapeutic re-enactment, she pictured herself again with an $\mathrm{X}$, this time in the safety of a studio (fig. 5). She later repeated this marking of the $\mathrm{X}$ onto a series of dolls (fig. 8), sometimes shaving their heads or cutting out their plastic breasts and documenting each stage of treatment/mutilation with the camera. Each performative re-enactment of the $\mathrm{X}$ marking the spot allowed Spence to subjectively invest herself in the process of her own clinical objecrification, and in so doing, perhaps to subvert it or cancel it out - X-ing out her own X-ing. 'Ihis repetition of the markthe stigmatic stain, the site of the wound-also allowed Spence to transfer the violence enacted upon her onto these insensitive dolls, whose visual mutilations bear potent witness to the invisible suffering Spence endured. The repetition of her wound

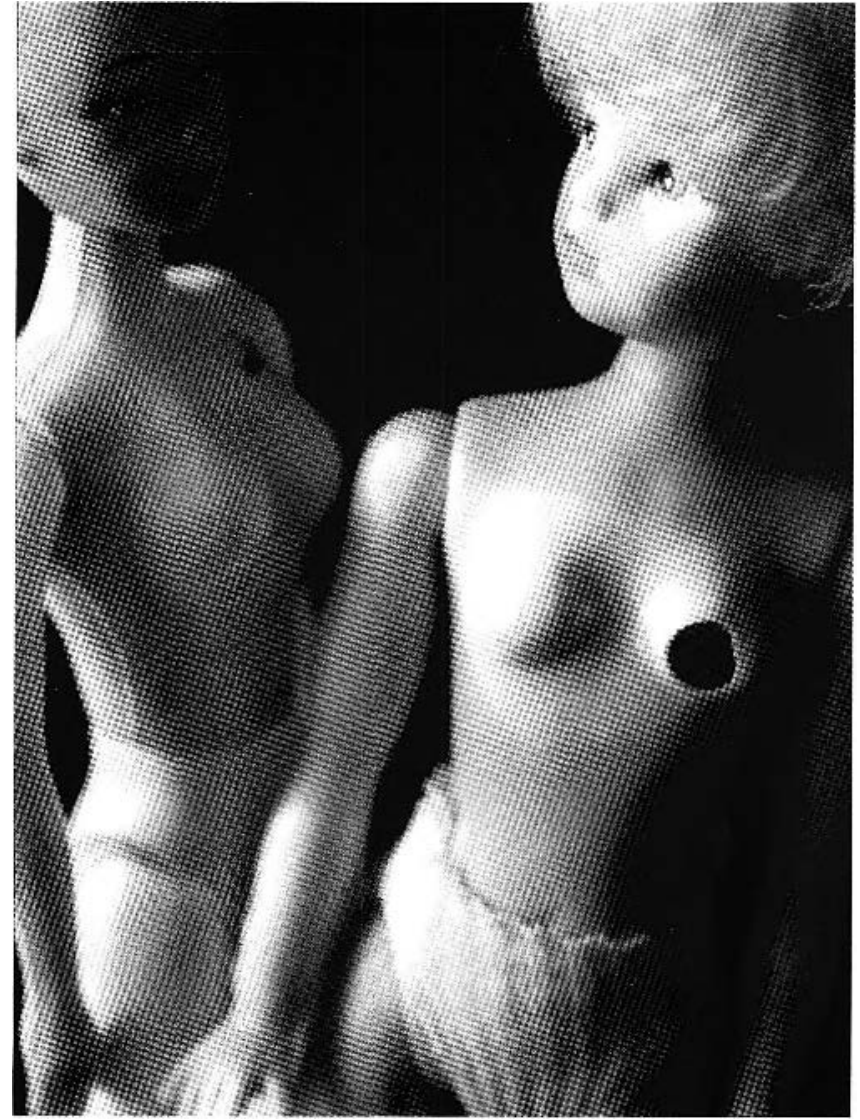

Figure 8. Jo Spence, Concer Sisters, 1982.83, from The Concer Project. Photograph, $70 \times 50 \mathrm{~cm}$ (C) The Jo Spence Memorial Archive)

indeed took on the power of an acting form. The very concept of phototherapy intrinsically assumes that the creative process plays a significant part in the curative onc, as it is through the re-articulation of the wound (in this case, through photo-theatre) that a potential healing takes place.

In stark contrast to the affective investment committed in her phototherapeutic practice, Spence documented her lumpectomy scar in a manncr reminiscent of Alphonse Bertillon's criminal photographic measurements: a cold, objective impression of the mark of surgery (fig. 9). Historically, the depiction of sick bodies in photography and painting has often shared characteristics with the depiction of criminals. In photographs employed for the study of physiognomy in the nineteenth century, for instance, specific visual stercorypes of illness were identified in order to localize and separate individuals touched by disease. Similarly, particular physiognomic characteristics were attributed to those engaging in criminal behaviours. ${ }^{32}$ Here, Spence operates with a measure of distance towards herself that mimics 

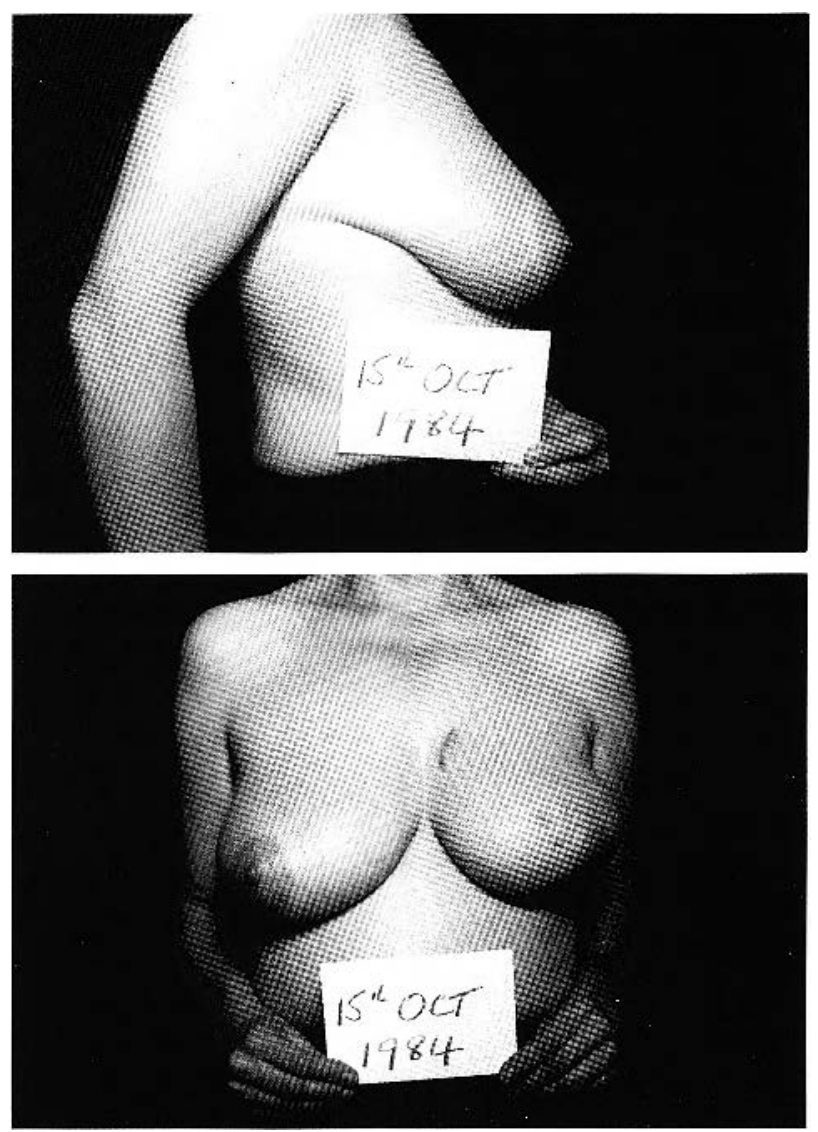

Figure 9. Jo Spence / Terry Dennett, 15th October. 1984, from The Cancer Project. Photographs, $50 \times 70 \mathrm{~cm}$ (C) The Jo Spence Memorial Archive).

the painfully objective perspective of her clinicians. Her wound is visually processed from the front and from the side, with a placard indicating the date of capture, as in a mug shot. Other than the fact that she is the one who took these photographs, there is no recognizable place for Jo Spence in this documentation of her illness-her face is absent from the frame.

The October 15th, 1984 photographs perform a detached re-enactment of how Spence was processed by the medical gaze, in a strategy that is similar to her compulsive repetition of the surgeon's mark of an X. In both cases, a medical process that objectified Spence's body is subverted by her firsthand reappropriation of the gesture. If the surgeon's $X$ and the medical photographer's reduction of the patient to the mark of her ailment each effectively negate the being who is ill, then Spence's affirmative adoption of both methods acts against her implicit erasure. Perhaps, in simply repeating these objectifying gestures for herself, she also enabled viewers to recognize the object of her critique more clearly. Spence's "anthropometric" photo- graphs make reference to a specific genre of medical photography, while also citing a history of stigmatic attributions to the sick body in representations at large. They show how her marked body and the experiences to which it has been subjected place her within the highly regulated socio-culcural context of the medical establishment, with its attendant (bio)power dynamics. The photographs also point to the fact that such power dynamics are maintained through conventions in visual representation. Hannah Wilke, on the other hand, exacerbated the extent to which her ill body was rcad as out of place in her autopathographic images, by framing it in symbolically charged poses that explicitly refer to the history of art. In adopting these well-established conventions, Wilke highlighted the fact that she no longer corresponded to these criteria, having lost both beauty and health. By insisting nonetheless on representing herself within these codes, Wilke critiqued their implicit discrimination. Whether through the use of strategic contradiction, or through the parodic citation of archetypal aesthetic motifs, both artists demonstrated how the exposure of their diseased bodies jostled conventional parameters of representation in medicinc and visual culturc.

\section{Photography and the Response to Mortality}

Almost ten years after being diagnosed with breast cancer, Spence fell ill with leukemia that eventually took her life. She developed a series entitled The Final Project, which has seldom becn publicly displayed. Part of the work involved going back to existing photographs Spence had produced and engaging with them anew through plural-image superimpositions. Through this layering technique, and thc concomitant rcinvestment of the past with the present and future, Spence constructed immediate confrontations to her own impending death, all the whilc blurring temporal lines in order to evoke both timelcssness and impermanence. Looking Death in the Eye (fig. 10) presents a direct coincidence berween the figure of death, pictured as a skull, and Spence. Instead of death coming to her, as in the medieval danse macabre, Spence is in a sense becoming death: time renders her skin transparent as the passage from living to dying is effected.

Similarly, her Decay Project /15th October, 1984 (fig. 11) confronts the cool detachment of the clinical gaze with the inescapable march of time. By projecting a decaying surface onto the skin of this criminally measured body, the disciplinary hold of the medical system is strangely dismantled. This double image could suggest that the sitter was cruelly left to rot. Such a reading would stir up anger towards the anonymity of patients in the medical system, the lack of humanization in their treatment, and the feeling that while thcy are the driving force of the medical enterprise they are ultimately left be- 


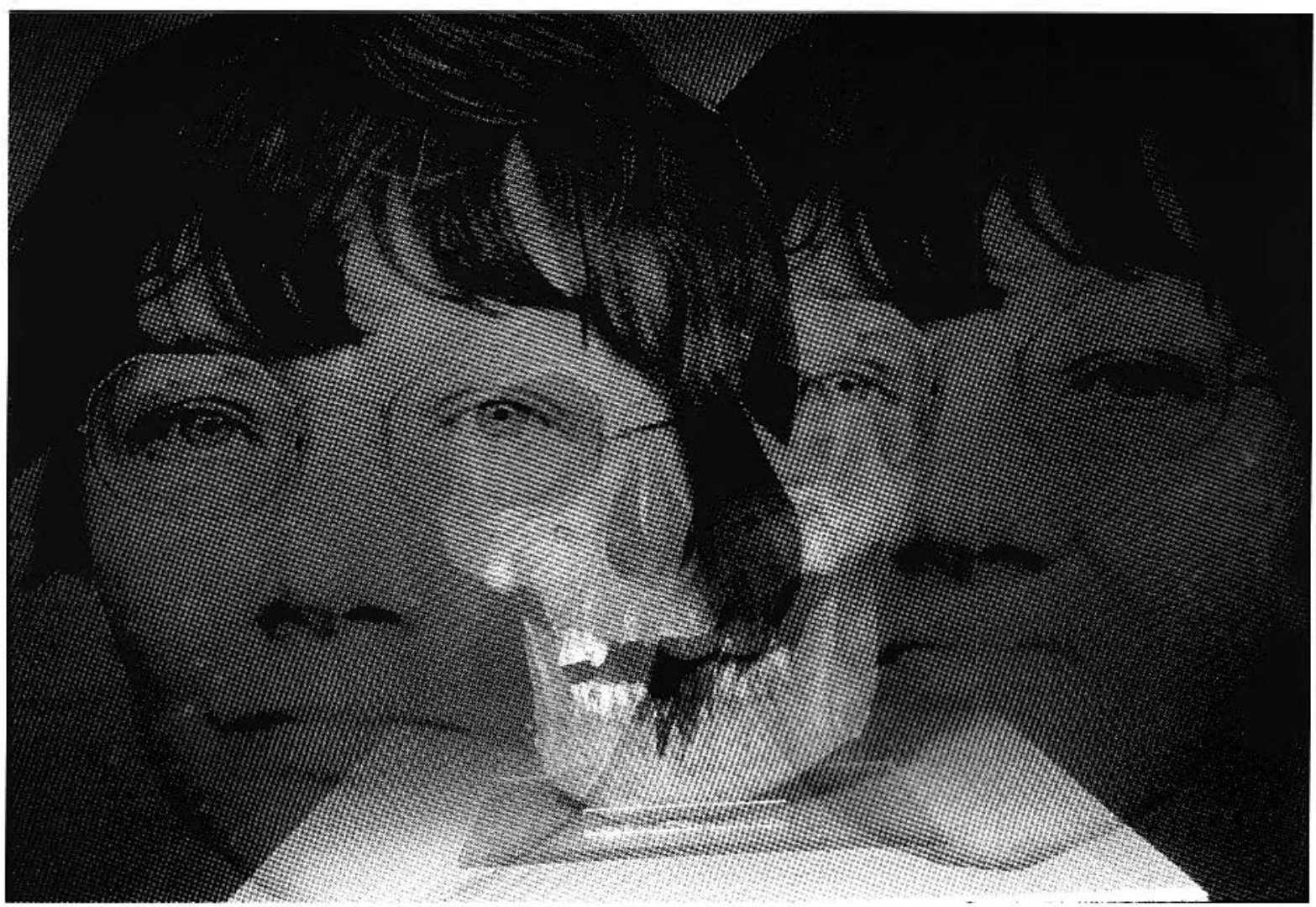

Figure 10. Jo Spence, Looking Death in the Eye, triple slide montage from The Final Project, 1991 92. Photograph, $70 \times 50 \mathrm{~cm}$ (C) The Jo Spence Memorial Archive).

hind. But another reading of the image could intuit that the sitter has transcended this medical hold, and that her decay is in this sense freeing. Such a reading leaves the viewer with the calm reassurancc that, no matter how hard the struggle, it too shall pass.

Like the medicval tradition of the Vado Mori, the Latin poem evoking a journey to death beginning with the statement "I prepare myself to die," the autopathographic work evokes an existential paradox involving simultaneity: it emphatically puts forward the fact that the processes of living and dying coincide spatially and temporally within the body of the suffering artist. Indeed, at what point can one say that the continuous present of the gerund verb "living" passes into that of "dying"? Although the self-representation of the artist in the photographic medium articulates itself in the present tense of the verb "to be"-I am in front of the camera, I am (still) alive and taking my own picture-the photographic print, as Roland Barthes reminds us, necessarily effects the communication of a moment that is past and also dead: "it has been." 33 All subjects of a photograph are by extension dead subjects, yet they present themselves with a haunting presence of life, a faint suggestion of motility despite the stasis of the camera shot.

What is the significance of the deployment of this gesture, which seeks to perform, document, and transmit this image of one's embodied, wounded-but-still-living self to another? Is there a continuous present at work in this act of sclf-deployment, reaching out to countless potential others, refusing the arrest of time? Guided by Barthes, what we can see in any photographic representation is the deployment in the continuous present of two somewhat contradictory moments: on the one hand, the gesturc of emission, which deploys itself from the photographic print to the image receiver; and on the other, the moment of life that was interrupted and capcured by the camera. The photographic capture effectively deadens that living moment by seizing the flow of time. Yet the resultant image remains indexically tied to this moment of living, and therefore contiguous to it, symbolically opposite and alike. The autopathographic photograph similarly maintains the authorial 
presence of the subject (as "what is left" of the "it has been") in the form of the photograph's punctum or aura. The print, therefore, might equally be regarded as the corpse of a subject that once was, and as a substitute body built for posterity by a subject that no longer is.

In the particular case of autopathographic production, there is a heightened equivalence betwcen the use of a photographic medium and the subject being represented: a human subject whose mortality is doubly exposed via the form and content of the photograph. In this twice-repcated, contiguous juxtaposition of living and dying, it would seem that a passage is also being effected from the realm of the aesthetic and the metaphysical to that of ethical human relations. While partially oriented towards a personal working through of the experience of living with illness, the autopathographic process also provides an occasion to collaborate with others in a symbolic or ritualistic manner, and to engage in a mutual bearing witness to the paradoxes of human life, the most striking of which is the fact of mortality. As we have secn, the finished product of these investigations seldom exhibits an affcctive resolution, but rather attests to the cnduring struggle of living. Wilke's and Spence's works are exemplary in their sustenance of such productive irresolution. While they may have been driven towards a restorative end, their self-portraits uphold the tensions and contradictions implicit to living with illness and in the face of death.

The autopathographic photograph attests to the fact of human mortality and to the inevitability of suffering. When faced with such an image, the viewer must decide whether or not to pay heed to its represented subjects. In exposing both real and symbolic wounds, the autopathographic photograph asks the viewer to bear witness to a fellow human being's experience: an experience that ultimately mirrors or foreshadows that of the viewer. The questions posed, then, in the act of reception are: Do I dare to take a look at this image? And if so, how should I respond?

As Sharon Sliwinski has noted, representations of diseased or mutilated bodies condition their viewers to shift from a mode of passive reception into one in which they take on the engaged responsibility of bearing witness to suffering. ${ }^{34}$ Simply put, Sliwinski suggests that due to the nature of their subject matter, images of the ill (as well as of victims of war or other atrocities) can transform disinterested viewers into witnesses. She reads two steps in the apprehension of the image of suffering. First comes a moment of recognition, which is marked by horror or revulsion. This is followed by "the work of responding" to the image, which she describes, using Barthes's words, as a "painful labour." 35 She writes: "The helplessness and horror of bearing witness to suffering brings with it the demand for a response, and yet one's response to photographs can do nothing to alleviate the suffering depicted." 36 Thus, the structure of

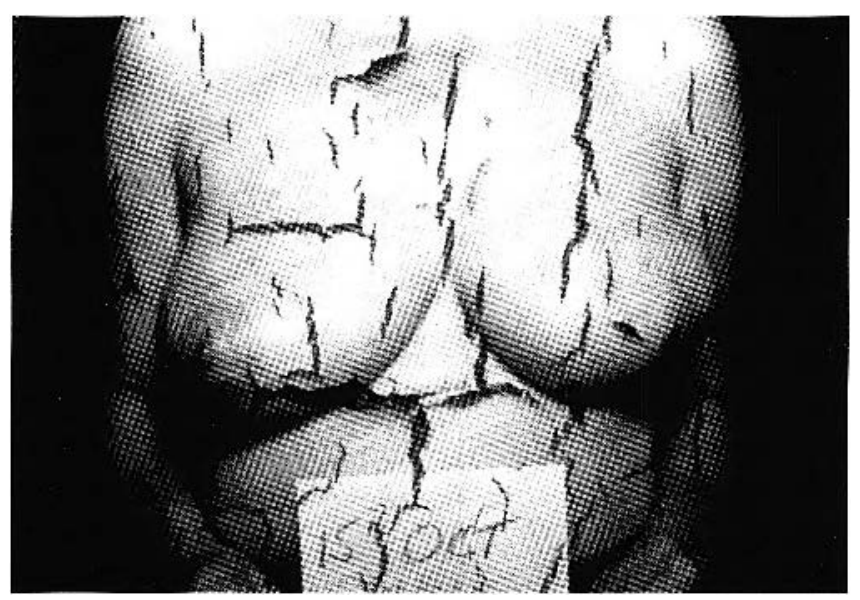

Figure II. Jo Spence / Terry Dennett, Decay Project / 15 Ih October, 1984. double slide montage for The Final Project. 1991-92. Photograph. $50 \times 70 \mathrm{~cm}$ (ㄷ Thc Jo Spence Memorial Archive).

the photograph is frustratingly limited for Sliwinski, because it prevents the viewer from "answering the call [that] it seems to emit." 37 In this sense the function of the photograph precisely becomes its devastating revelation of our "utter inability to prevent suffering." 38

This affirmation constitutes a constructive, potentially cthical opening in the autopathographic image at the level of its reception. As we can see through the works of Wilke and Spence, the autopathographic photograph does not project the viewer into a complacent sense of "having done good" simply by looking at the image. Rather than offering closure, it continues to raise the dialectical tensions between illness and health, living and dying, subject- and object-hood in representation, and shows them as remaining unresolved. The photograph not only says, "Witness me, in all my specificity: I am suffering," which might suggest exhibitionist narcissism on behalf of the artist. It does not either strictly repcat, like the medieval figure of death, "As I am, thou shalt be," 39) which would function as a memento mori. The autopathographic photograph also potentially states: "Witness the fact that you are powerless before my pain, which is also your pain. Suffering and mortality are the bases of our human condition."

The burden of responding to this dual affirmation of powerlessness rests upon the viewer. This is achieved not only by the fact that the vicwer is transformed into a witness before the artist's depicted suffering, but also by the fact that the autopathographic image appeals to the viewer to respond to the fact that she cannot respond, that she is impotent before fate and therefore must make a choice as to how to behave in such a predicament. Autopathographic communication is thus revealed to be 
dialogical in nature, in that receivers must act back in response to the image, even if this action consists of closing their eyes. Amelia Jones refers to the image's call for a responsc as the "not yet" potential of the photograph, which complements Barthes's notion of "having been." 40 In Jones's logic, Barthes's "corpsed" image becomes enlivened again through the acts of reception by which it is met. "II This is yet another means by which the autopathographic image becomes performative, as a dead imprint transforming itself in to a vehicle for renewed life.

Through examples of works by Wilke and Spence, we have seen that autopathographic images are often invested with a transformative power that is reminiscent of traditional acting forms, such as talismans and ex-votos. What is particular to these contemporary images, however, is their direct appcal to a spectator, and the fact that their performative power might eventually spill over onto him or her in a variety of ways. In Spence's and Wilkc's phorographs, the viewer is addressed by a dying subject, one who once truly lived before the camcra. The temporally deferred bcaring witness of the other's failing health and encroaching death, a bearing witness which occurs in the moment of image reception, is the very time and place of an ethical passage: a passage which can only occur in relation, from one mortal being to another, and whose porential here is transmitted by a photograph. This photograph, then, is not just the mark, the document, or the testimony of a once-living individual. It remains filled with a potential that continues to invite this bearing witness on behalf of the receivcr-and so, in this sense, the photograph is still alive, in spite of or because of its own multiple deaths.

\section{Acknowledgements}

The author thanks Terry Dennett and the Jo Spence Mcmorial Archive for reproduction rights and access to unpublished materials, as well as Donald Goddard, and Marco Nocella at the Ronald Feldman Fine Arts Gallery, for permission to reproduce Hannah Wilke's images. Warm thanks are also extended to Claudette Lauzon and to the editors, Allister Neher and Mireille Perron, for their thoroughness in reviewing this papcr.

\section{Notes}

1 See Sander Gilman, Disease and Representation: Images of Illness from Madness to AIDSS (Ithaca, 1988), and Picturing Health and Il!ness: Images of Identity and Difference (Baltimore, 1995); as well as Susan Sontag, Illness as Metaphor \& AIDS and its Metaphors (Ncw York, 1990).

2 See Thierry Davila, "Fsthétique et Clinique: Brève Introduction à l'Art Médecin," l'Art Médecine, ed. Maurice Fréchuret and Davila (Paris, 1999), 34-63, csp. 41.
3 Arthur W. Frank, At the Will of the Body: Reflections on Illness (Boston, 2002), 1-7.

4 Free translation of: "il s'agit pour l'image de dépasser le cadre exclusif de la pure contemplation ou vénération distanciée afin d'accéder à un domaine où l'action directc sur lcs événements et les corps constitue sa véritable raison d'être." Thierry Davila, "Esthétique et Clinique," 51-52. My translations unless otherwise indicated.

5 Judith Butler, (Giving an Account of Oneself (Ncw York, 2005).

6 Burler, Giving an Account of Oneself, 32.

7 Anne Hunsaker Hawkins, a specialist in the analysis of literary parhographics, concurs. See her Reconstructing Illness: Studies in Pathography (Wcst Lafayette, 1998), 15.

8 Amelia Jones, "The 'Fternal Return': Self-Portrait Photography as a Technology of Embodiment," Signs 27, 4 (2002): 947-78, csp. 950.

9 Butler's reflection on the construction of subjecthood is grounded in her deconstruction of gender. See her Gender Trouble: Feminism and the Subversion of Identity (London, New York, 1990), and Bodies that Matter: On the Discursive Limits of Sex (London, New York, 1993).

10 On Wilke's place in the history of feminist art, see Saundra Goldman, "Heresies and History: Hannah Wilkc and the American Feminist Art Movement," Hannah Wilke: Exchange Values (Vitoria-Gasteiz, 20()6).

11 See Annette Kubitza, "Die Tyrannei der Venus," Hannah Wilke 1940-1993, ed. Stcfanie Kreuzer (Berlin, 2000), 103-13, esp. 104-05.

12 See Kubitza, "Die Tyrannei der Venus," 111; and Joanna Frueh, "Feminism," Hannah Wilke: A Retrospective, ed. Thomas H. Kochheiser (Columbia, 1989), 41-50, esp. 44.

13 Physical pain is both pre-objective and pre-linguistic. "Physical pain does not simply resist language but actually destroys it, bringing about an immcdiate reversion to a state anterior to language, to the sounds and cries a human being makes bcforc language is learned." Elainc Scarry, The Body In Pain: The Making and Unmaking of the World (Oxford, 1985), 4. See also Jean Jackson, "Chronic Pain and the Icnsion Between Subject and Object," Embodiment and Experience: The Existential Ground of Culture and Self, ed. Thomas J. Csordas (Cambridge, 1994), 201.

14 Hannah Wilke interviewed in Cassandra Langer, "The Art of Healing," Ms., January/February 1989, 132-33, esp. 132.

15 Joanna Frueh, "Mother," Hannah Wilke: A Retrospective, cd. Thomas H. Kochhciscr (Columbia, 1989), 79-89, esp. 87.

16 Arthur Kleinman, The Illness Narratives: Suffering, Healing, and the Human Condition (New York, 1988), 22.

17 See Erving Goffman, Stigma: Notes on the Management of Spoiled Identity (Englcwood Cliffs, 1963).

18 In developing her symbolic wounds as exoskclcton, Wilke was also referring to being "marked" by her Jewish identity. In the performance Intercourse With... (1977), she states: "To also rcmember 
that as a Jew, during the war, I would have been branded and buried had I not becn born in America." Transcript of the performance reprinted in Kochheiser, ed., Hannah Wilke, 140.

19 Term invented by Wilke and used to describe all her self-portraits, emphasizing the wilfully performative and formalist aspects of her practice.

20 Luce Irigaray, This Sex Which Is Not One, trans. Catherine Porter (Ithaca, 1985), 26.

21 "Skin-ego" is a translation of Didier Anzieu's notion of the "moipeau," which draws a parallel between the skin's physiological function as a bodily boundary/interface and its symbolic delincation of a permeable sphere describing the sclf. Didier Anzieu, Le Moi-Peau (Paris, 1993).

22 Saundra Goldman, "Hannah Wilke: Gesturc and "Ihe Regeneration of the Universe," Hannah Wilke: A Retrospective, ed. Elisabeth Delin Hansen et al., cxh. cat., Nikolaj, Copenhagen Contemporary Art Center (Copenhagen, 1998), 6-43, esp. 40.

23 See chapter five in Simon J. Williams, Medicine and the Body (London, 2003).

24 Howard Brody, Stories of Sickness (New Haven, 1987).

25 Jean-I.uc Nancy, L'Intrus (Paris, 2000), 39.

26 Free translation of "la santé, c'est la vie dans le silence des organes." René Leriche, originally quotcd in Georges Canguilhem, "Essai sur Quelques Problèmes Concernant le Normal et le Pathologiquc," Le Normal et le P'athologique, Augmenté de Nouvelles Réflexions Concernant le Normal et le Pathologique (Paris, [1943] 1966), cited in David Le Breton, Anthropologie de la Douleur (Paris, 1995), 23.

27 Personal interview with Marco Nocella, curator, Ronald Fcldman Fine Arts Gallery, New York City, 27 July 2006.

28 Sontag, Illness as Metaphor, 3.

29 Talcott Parsons' formulation of the "sick role" in the 1950s cffectively launched the field of medical sociology. Its primary characteristics include the "exemption from normal role obligations," the "lack of responsibility for illness," the "desire to get well, and the seeking of technically competent hclp." Williams, Medicine and the Body, 182, emphases removed.

30 Personal intervicw with Terry Dennett, director, Jo Spence Memorial Archive, 26 April 2006, London, England.

31 Rosy Martin, "Putting Us All in the Picture: The Work of Jo Spence," Camera Austria 43/44 (1993): 43.

32 Sander Gilman, in Picturing Health and Illness, develops the notion of an "iconography of medicine" (p. 17) in order to study the roles of images in the development of nosology, or the classification of diseases. In chapters one and two of this book, he examines early photography's contribution to the discipline of physiognomy in helping to identify physical types that were thought to be prone to mental illness and other deviant behaviours.

33 Roland Barthes, Camera Lucida: Reflections on Photography (New York, [1981] 2000).

34 Sharon Sliwinski, "A Painful Labour: Responsibility and Photo- graphy," Visual Studies 19, 2 (October 2004): 150-161. Sliwinski notes that her position runs against Sontag's, who posits that the photograph is a site of ethical failure because it is an "act of non-intcrvention," both in the moment when the picture is taken and in the moment when the photograph is viewed. See Susan Sontag, On Photography (New York, 1977), esp. 11, and Regarding the Pain of Others (New York, 2003). It is possible, however, that the charge of ethical failure does not hold when applied to self-representations, as opposed to the capture of other people's suffering. Neverthcless, the question of an ethically adequate representation of suffering largely remains unrcsolved in trauma and witness studies.

35 Sliwinski, "A Painful Labour," 154 and 150, citing Barthes, Camera Lucida, 66.

36 Sliwinski, "A Painful Labour," 154. Fmphasis in original.

37 Sliwinski, "A Painful Labour," 155.

38 Sliwinski, "A Painful Labour," 155.

39 Phrase typically spoken by the figurc of Death in medicval morality plays and in depictions of the dance of death.

10 Jones writes: "[T]he 'having been' [ ça a été] tense of the photograph [is] transferred into the 'not yet' of future possibilities" through the acts of reception and interpretation. Jones also notes that ccrtain works "insistently enact the photograph's capacity to mark the death of the subject; in so doing, they paradoxically open this subject to the 'life' of memory and the interpretive exchange." Jones, "The 'Eternal Rerurn," csp. 976 and 975.

41 On the photographic image as corpse, see Barthes, Camera Lucida, 78. 